\title{
Germination of Senna Occidentalis Link: Seed at Different Osmotic Potential Levels
}

\author{
Maria Elena Aparecida Delachiave ${ }^{1 *}$ and Sheila Zambello de Pinho ${ }^{2}$ \\ ${ }^{1}$ Department of Botany; C. P. 510; CEP 18618-000; Botucatu - SP - Brazil. ${ }^{2}$ Department of Biostatistics; C. P. 510; \\ CEP 18618-000; Botucatu - SP - Brazil
}

\begin{abstract}
The objective of this research was to study the effect of osmotic potential and salinity on the germination of seeds of Senna occidentalis, with and without a change of solutions. The percentage and rates of germination decreased according to decrease of potential, being more drastic when the substitutions of solutions were not made. The largest reductions were observed with the PEG solutions, with and without substitutions.
\end{abstract}

Key words: Germination, seed, osmotic potential, Senna occidentalis

\section{INTRODUCTION}

Water stress acts by decreasing the percentage and rate of germination (Prusinski and Khan, 1990; Branccini et al., 1996), and for each species there exists a value of water potential below which germination does not occur (Bewley and Black, 1985). In order for the process of germination to start, it is necessary for the seed to reach an adequate level of hydration, which will permit a reactivation of the metabolic processes (Cordoba et al., 1995). Nassif and Perez (1997), studying germination in Pterogyne nitens, observed that PEG 6000 provoked larger decrease in the percentage and rate of germination of the seeds than did $\mathrm{NaCl}, \mathrm{CaCl} 2, \mathrm{KCl}$, and manitol, there occurring no germination at $-1.2 \mathrm{MPa}$ with PEG, and -2.2 MPa with $\mathrm{NaCl}$.

Senna occidentalis presents promising results in biological activity against the etiological agent of malaria (Sala-Neto et al., 1990), and its leaves, as infusions, are purgative and emenagogous; the roots are vermicide, diuretic, abortive, and disobstructive (Lorenzi, 1982). As literature is scanty regarding germination of seed in medicinally potential species, the objective of this study was to verify the effects of osmotic potentials and salinity on the germination of seeds of this species, with and without changes of solution.

\section{MATERIAL AND METHODS}

The osmotic potentials utilized were 0 (control), -0.2 ; -0.4 and $-0.6 \mathrm{MPa}$, with 3 replications with 50 seeds, previously scarified in concentrated sulfuric acid for $20 \mathrm{~min}$, then washed in running water. The seeds were placed for germination under lighting conditions for $24 \mathrm{~h}$ (4 fluorescent lamps of $40 \mathrm{w}$ ) at $25^{\circ} \mathrm{C}$ on humidified filter paper with $12 \mathrm{ml}$ of solution at different potentials. For the relationship between concentration and potential with the PEG (polyethylene glycol 6000)

\footnotetext{
* Author for correspondence
} 
solution, the Villela et al. (1991) table was used, and for the $\mathrm{NaCl}$ solution, the equation cited by Parmar and Moore (1968) was used. As it was noticed that alterations occurred in the refractometric indexes of the solutions, the germination tests were done with and without changing solutions, and changing at 2 hours intervals for the PEG, and 4 hours intervals for the $\mathrm{NaCl}$ solutions in the 24 early hours and after the widely intervals, according to refractrometric indexes variations.

Observations of germination were made daily during 10 days, being considered as having germinated those seeds that presented approximately $2 \mathrm{~mm}$ of root length (Rehman et al., 1996), which were removed. The rate, or velocity, of germination was calculated according to the formula of Maguire (1962). For statistical analysis, the data of germinating percentage were transformed to $\arcsin \sqrt{X / 100}$. The design was a completely randomized one, and the averages compared by the Tukey method, at 5\% level of probability.

\section{RESULTS AND DISCUSSION}

The final percentage results (Fig. 1) and the velocity of germination (Fig. 2) presented decrease as the potential went from 0 to $-0.6 \mathrm{MPa}$ in PEG and $\mathrm{NaCl}$ solutions, and was more drastic with PEG at -0.6 MPa, both with and without changing solution. When the potentials were PEG induced (Fig. $1 \mathrm{~A}$ ) and the solution was renewed, the percentage of germination decreased from -0.4 $\mathrm{MPa}$ potential; when the solutions were not changed the decreasing was more accentuated at $-0.2 \mathrm{MPa}$. The velocity of germination decreased rapidly with decrease of potential induced by PEG (Fig. 2 A), when a significant difference appeared with $-0.2 \mathrm{MPa}$, with or without change of solution. In Fig. $1 \mathrm{~B}$, it could be seen that when the $\mathrm{NaCl}$ solutions were changed, the final percentages of germination did not differ significantly between the potentials used; however, with regard to the velocity of germination (Fig. 2 B), the data showed differences starting with $-0.2 \mathrm{MPa}$, showing drastic reduction at $-0.6 \mathrm{MPa}$. The change in the refractometric index of the $\mathrm{NaCl}$ solutions could have been due to the absorption by the seeds (Reman et al., 1996), where the content of $\mathrm{Na}^{+}$of the seeds, of the three species of Cassia tested, increased with the increase of the concentration of $\mathrm{NaCl}$ in the solution. However, when the $\mathrm{NaCl}$ solutions were not changed (Fig. 1 B), a significant difference was observed starting at -0.2 $\mathrm{MPa}$, no germination occurring at $-0.6 \mathrm{MPa}$, the same pattern was observed with the velocity of germination (Fig. $2 \mathrm{~B}$ ).

Analyzing the results of percentage and rate of germination in $\mathrm{PEG}$ and $\mathrm{NaCl}$ solutions, it was seen that the decrease of potential affected the velocity more than the final percentage of germination, which agreed with the results found by Ashraf and Abu-Shakra (1978) and Nassiff and Perez (1997). The largest reduction found, both for final percentage and rate of germination when the seed treatment with PEG was compared to $\mathrm{NaCl}$ treatment, was also observed by Nassiff and Perez (1997) in seeds of Pterogyne nitens, where the limit of germination was -1.0 MPa for PEG and $-1.8 \mathrm{MPa}$ for $\mathrm{NaCl}$, with velocity being more affected than germination potential. To Senna occidentalis the germination limit would be -0.2 $\mathrm{MPa}$ for PEG and $\mathrm{NaCl}$ solutions, without solutions changes, and -0.6 MPa for PEG and less than $-0.6 \mathrm{MPa}$ for $\mathrm{NaCl}$, with change of solution. This larger reduction, with PEG solution, when unchanged, could be attributed to high viscosity, where solubility and diffusion of oxygen were reduced compared to water (Mexal et al., 1975). Furthermore, by the same manner that PEG, of high molecular weight is excluded from cell walls, it is also excluded from the cellulose matter of filter paper (Hardegree and Emmerich, 1990), that with water absorption by the paper and by the seeds concentrate the free solution, resulting in the decrease the water potential value.

When the potential was sufficiently low, such as $-0.6 \mathrm{MPa}$ with no change of solution, the seeds could contain sufficient water (Bradford, 1990) to start the germination process (Phase I and II) without however, passing to root cell growth (Phase III). The process of elongation and the cellular wall synthesis are highly sensitive to water deficiency (Wenkert et al., 1978) and reduction in growth could be due to the decrease of turgor of these cells (Bradford, 1995). 
A) PEG

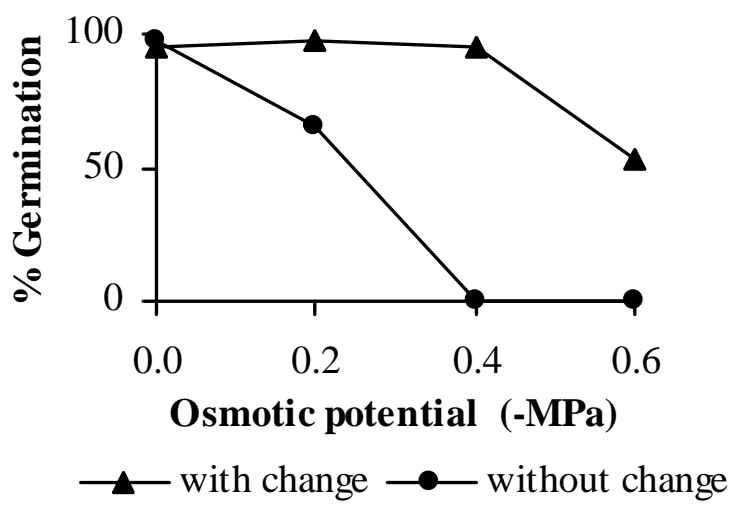

B) $\mathrm{NaCl}$

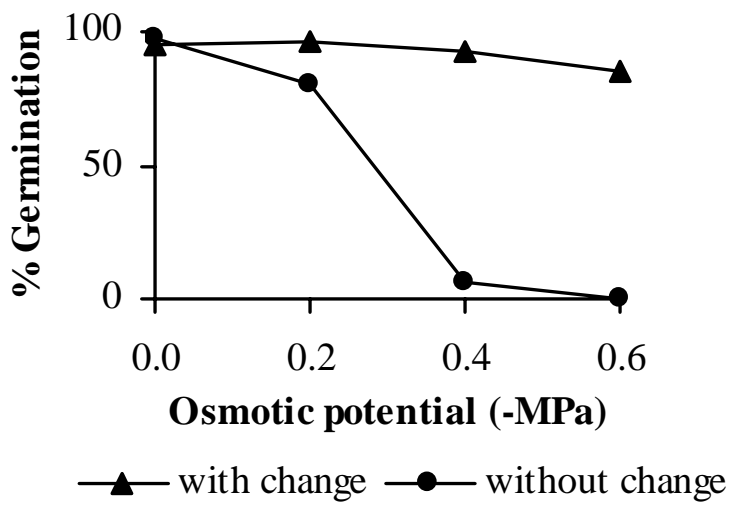

Figure 1 - Average percentage of germination of seeds of Senna occidentalis, submitted to different osmotic potentials with and without a change of solution, induced by PEG (A) and $\mathrm{NaCl}(\mathbf{B})$, under light, at $25^{\circ} \mathrm{C}$.

A) PEG

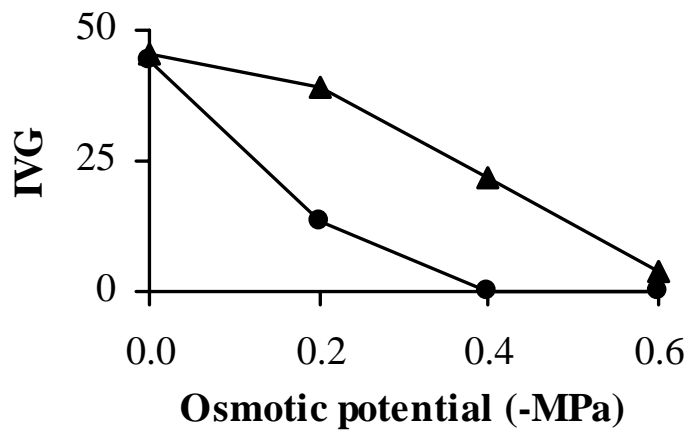

$\longrightarrow$ with change $\longrightarrow$ without change
B) $\mathrm{NaCl}$

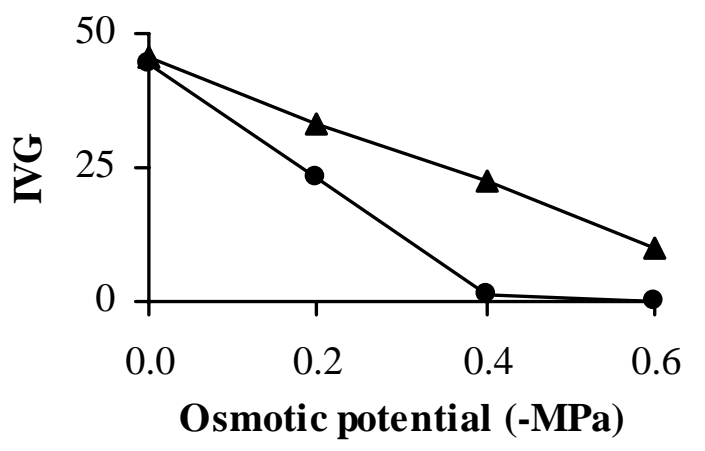

$\longrightarrow$ with change $\longrightarrow$ without change

Figure 2 - Average velocity of germination (IVG) of Senna occidentalis seeds, submitted to different osmotic potentials with and without change of solution, induced by PEG (A) and $\mathrm{NaCl}(\mathbf{B})$, under light, at $25^{\circ} \mathrm{C}$.

\section{ACKNOWLEDGEMENT}

The first author thanks CNPq for providing support (Process n ${ }^{\mathrm{o}}$. 300548/85-0).

\section{RESUMO}

O objetivo da pesquisa foi estudar o efeito de potenciais osmóticos e salinidade na germinação de sementes de Senna occidentalis, com e sem troca da solução. A porcentagem e a velocidade de germinação diminuíram com o decréscimo do potencial, sendo mais drástica quando as soluções não foram trocadas. As maiores reduções foram observadas nas soluções com PEG, com e sem troca da solução.

\section{REFERENCES}

Ashraf, C. M. and Abu-Shakra, S. (1978), Wheat seed germination under low temperature and moisture stress. Agronomy Journal, 70, 135-139. 
Bewley, J. D. and Black, M. (1994), Physiology of development and germination. New York : Plenum Press. pp. 147-197.

Braccini, A. L.; Ruiz, H. A.; Braccini, M. C. L. and Reis, M. S. (1996), Germinação e vigor de sementes de soja sob estresse hídrico induzidos por soluções de cloreto de sódio, manitol e polietileno glicol. Revista Brasileira de Sementes, 18, 10-16.

Cordoba, G. A. T.; Borges, E. E. L.; Borges, R. C. G. and Neves, J. C. L. (1995), Osmocondicionamento em sementes de Esenbeckia leiocarpa Engl (guarantã). Revista Brasileira de Sementes, 17, 217-226.

Hardegree, S. P. and Emmerich, W. E. (1990), Effect of polyethylene glycol exclusion on the water potential of solution-saturated filter paper. Plant Physiology, 92, 462-465.

Lorenzi, H. (1982), Plantas daninhas do Brasil: terrestres, aquáticas, parasitas, tóxicas e medicinais. Nova Odessa : Instituto Plantarum. pp. 257.

Maguire, J. D. (1962), Speed of germination-aid in selection and evluation for seedling emergence and vigor. Crop Science, 2, 176-177.

Mexal, J.; Fisher, J. I.; Osteryoung, J. I. and Reid, C. P. (1975), Oxigen availability in polyethylene glycol. solutions and its implications in plant water relations. Plant Physiology, 55, 20-24.

Nassiff, S. M. L. and Perez, S. C. J. G. A. (1997), Germinação de sementes de amendoim-do-campo (Pterogyne nitens Tul.): influência dos tratamentos para superar a dormência e profundidade de semeadura. Revista Brasileira de Sementes, 19, 172-179.

Parmar, M. T. and Moore, R. P. (1968), Carbowax 6000 , mannitol and sodium chloride for simulating drought conditions in germination studies of corn (Zea mays L.) of strong and weak vigor. Agronomy Journal, 60, 192-195.
Prusinski, J. and Khan, A. A. (1990), Relationship of ethylene production to stress alleviation in seeds of lettuce cultivars. Journal American Society of Horticulture Science, 115, 294-298.

Rehman, S.; Harris, P. J. C.; Bourne, W. F. and Wilkin, J. (1996), The effects of sodium chloride on germinating and the potassium and calcium contents of Acacia seeds. Seed Science and Technology, 25, 45-57.

Sala-Neto, F.; Nascimento, N. P.; Mattos, J. K. A. and Costa, C. E. (1990), Efeito inibitório da Cassia occidentalis sobre o crescimento da Plasmodium falciparum, in vitro: avaliação da estabilidade. Anais do II Simpósio de Malária, 38, Ministério da Saúde UnB-OPAS. Brasília.

Villela, F. A.; Doni Filho, L. and Sequeira, L. E. (1991), Tabela de potencial osmótico em função da concentração de polietileno glicol 6000 e da temperatura. Pesquisa Agropecuaria Brasileira, 26, 1957-1968.
Received: July 16, 2001; Revised: March 27, 2001; Accepted: July 09, 2002. 